\title{
Study of Length-weight relationship and the condition factors of Lepidocephalichthys guntea (Hamilton, 1822) from Kangsabati river of district West Midnapore, West Bengal, India.
}

\author{
Sayan Mandal I Basudev Mandal* \\ Department of Fishery Sciences, Vidyasagar University, Midnapore-721102, West Bengal, India \\ *Correspondence: bmandal@ mail.vidyasagar.ac.in / bmandalamtvu@gmail.com
}

\section{Abstract:}

The Peppered loach, Lepidocephalichthys guntea is the least concerned freshwater species, commonly found in India, Pakistan, Nepal, and Bangladesh. In West Bengal, it is popularly known as "Guntey" \& it has commercial and food value. The current study aimed to the estimation of the length-weight relationship, condition, and relative condition factor $(K n)$ of the fish species Lepidocephalichthys guntea, habitats of Kangsabati river in the District West Midnapore, West Bengal, India. Total 161 numbers of species were collected between August 2019 to July 2020 and considered for examination. The fishes ranged from 5.4 to $10.7 \mathrm{~cm}$ in total length \& 0.72 to $9.73 \mathrm{~g}$ in weight. The scatter diagram exhibits a linear relationship between the log length \& log weight. The female species has a higher " $b$ " value $(b=3.452, P<0.05)$, which is greater than 3 which justifying a positive allometric growth. The parabolic equation among total length and weight of L. guntea is labeled as $W=0.008744991 L^{2.7496}$ for males, $W=$ $0.002153098 L^{3.452}$ for females \& $W=0.007575793 L^{2.8155}$ for the combination of male and female species. Higher $r^{2}(0.859, P<0.05)$ value in combined of male \& female justifying a strong relationship between length and weight. The mean condition $(K) \&$ relative condition factor $(K n)$ values were found to be the height in the male category with " $K$ " value 0.654 \& "Kn" value 1.174 respectively indicating the well-being of the species. Although, this species does not sternly follow the cube law \& shows a well status of health condition in their natural habitat.

\section{Keyword:}

Lepidocephalichthys guntea, Length-weight relationship, Kangsabati River, Condition factor.

\section{Introduction:}

The essential chef source of protein is taken for consideration is "the fish". It also provides a source of income to many peoples all over the world. Fishes are cultured in ponds, rivers, reservoirs, and marine(cage culture). Besides capture fisheries, agriculture sector and urbanization also escalating very high, due to that reasons overfishing, agricultural \& urban waste runoff are increasing and wetlands area are decreasing. These factors affecting fish stocks and health very seriously. To know about the health conditions of fishes there are many characters to study, one of them is the Length-weight relationship study. The condition factor (K) \& relationship between length-weight (LWR) are two imperative needles in the supervision of the culture systems as it delivers information's on the precise conditions of the growing environments of fish(Araneda et al., 2008). The quantitative parameter condition factor is assessed based on the length-weight statistics, which designates the wellbeing states of any fish (Hossain et al., 2006). The data of fish Length-weight are requiring standard outputs of the sampling programs (Morato et al., 2001). It is also required to estimate the rate of growth, age, and length structures of fish populations dynamic (Kolher et al., 1995). The Length-weight 
relationships are needed for comparing the morphological aspects and life history of inhabiting populations in different regions (Goncalves et al., 1997; Stergiou and Moutopoulos, 2001). The information about length-weight relationships (LWR) is a vital means for the passable management of any species of fish, that have been pragmatic in fish stocks and populations assessment (King, 2007; Lopez et al. 2020). It is also suitable in interregional \& local morphological contrast of populations (Froese, 2006; Ali et al., 2013). The Length-weight relationship (LWR) information of fishes is convenient for biologists (Martin-Smith, 1996) in the assessment \& proper management of fish populations. The study of Length-weight relationships also give baseline information about growth pattern estimation of the fish stocks, and strategies for conservation (Ortega-Garcia et al. 2017) The biology use length-weight relationship for numerous purposes like to envisage weight from measurements of length for the assessment of yield, the standing crops biomass calculation, estimation of age concerning the weight of the fish, fish population well-being index evaluation, to evaluate age structure \& function of the fish populations, studies the growth, differentiation of stock, ecological modeling and for the acoustic survey(Pauly, 1993; Petrakis and Stergiou, 1995; Haimovici and Velasco, 2000; Ozaydin et al., 2007; Froese 2006; Siddique et al. 2016; Eduardo et al. 2019). The LWR has been cast-off to get the information about the fish condition to estimate whether the somatic growth is allometric or isometric (Gurkan and Taskavak, 2007; Ujjania et al., 2012). In general, the fishes follow the cube law of growth pattern (Brody, 1945; Lagler, 1952). It may vary from fish to fish depend upon their health condition and different environmental factors (Le Cren, 1951). The relationship among Length-weight \& condition factors of several fishes has been reported previously (Le Cren, 1951; Lal and Dwivedi, 1965; Narasimham, 1970; Pathak,1975; Soni and Kathal, 1979; Shrivastava and Pandey, 1981; George et.al., 1985; Dasgupta,1988; Dhasmana and Lal, 1993; Azad and Nasar, 1996; Narezo et.al., 2002; Zaydın et. al. 2007; Pal et. al.(2013, 2014) Iqbal et. al.(2018); Amponsah et. al. 2021; Habib et.al. 2021; Panicker, B.A., \& Katchi, VI 2021). The species named Lepidocephalichthys guntea (Hamilton, 1822)have been categorized into the Cypriniformes order and Cobitidae family, it has commercial food and ornamental values in India. The species Lepidocephalichthys guntea is locally known by the name "Guntay" in West Bengal(India). The common name of the species in English are the Peppered loach, Scavenger loach, and Guntea loach and is categorized under "least Concern" in IUCN red data book(www.iucnred.list). The species are distributed over Pakistan, central, east, and northern India, Bangladesh, Nepal and it also recorded from Thailand \& Mayanmar (www.iucnred.list), they are generally habitat on the bottoms of swamp, streams, flooded fields, lakes, ponds, canals in the stream of Brahmaputra and Ganges river (Havird and Page, 2010).

In previous, several researchers have studied the LWR of Lepidocephalichthys guntea. ( Dhakal and Subba 2003; Hossain 2010; Gohain and Deka 2017; Kumar et. al. 2017). Nevertheless, so far no data has been published on LWRs of Lepidocephalichthys guntea, from the state West Bengal(India) as IUCN declared this species as "Least Concern". This study has been carried out to estimate the length-weight relationship of Lepidocephalichthys guntea, which was found in the kangsabati river and its tributaries (small narrow canals).

\section{Materials and methods:}

A total of 161 numbers of freshly caught species were collected from the Gate Bazar, a major fish market of Midnapore city in West Bengal, India during the periods August 2019 to July 2020. Through a market survey, it was coming to known that, all the species (Lepidocephalichthys guntea)(Plate 1.a) were caught from the river kangsabati and its tributaries. 
The collected species were stocked in two rectangular cemented tanks in the Department of Fishery Sciences of Vidyasagar University. A complete study has been carried out in the laboratory of the Fishery science department. Fish species were identified and differentiated sexually following the

described characteristic according to Talwar and Jhingran (1991) and Havird and Page (2010). Without any time laps the freshly caught species from their natural habitat the length and weight were measured on the same day of collection. The body color may get faded, a health condition may weekend with the time, when fishes are taken out of their natural habitats, for this reason, an immediate study of sexual dimorphism and length-weight data has been recorded. The length was measure nearer to $0.01 \mathrm{~mm}$ total length (TL), with digital Vernier caliper (Aerospace Plate 1.b) \& weight was measured nearest to $0.01 \mathrm{~g}$ total weight (TW) using digital mini heng pocket scale(MH-696)(Plate 1.d). The relationship between the length and weight of the fishes was calculated using the equation $\mathrm{W}=\mathrm{a} \mathrm{L}^{\mathrm{b}}$ (Le Cren, 1951 and Froese, 2006), in which $\mathrm{W}$ is the measure of total body weight( in grams) \& $\mathrm{L}$ is the measure of total length (TL) in $\mathrm{cm}$. Using the linear regression equation of length-weight relationships ( $\log \mathrm{TW}=\log \mathrm{a}+\mathrm{b} \log \mathrm{TL}$ ), a and $\mathrm{b}$ regression parameters were estimated.

Condition Factor:

Fulton condition factor of the species (Fulton, 1904) was estimated using the equation $\mathrm{K}=100$ $\mathrm{W} / \mathrm{L}^{3}$ ( Where $\mathrm{W}$ is species weight in grams, $\mathrm{L}$ is species total length in centimeter). The Relative condition factor was estimated using the following formula: $\mathrm{Kn}=\mathrm{W} / \mathrm{aL}^{\mathrm{b}}$, (Where $\mathrm{W}$ denotes species total weight in grams, $\mathrm{L}$ denotes species total length in centimeter, $\mathrm{a}$ and $\mathrm{b}$ are the regression parameters).

\section{Data analysis:}

The correlation among the variables was figured by the coefficient $" r^{2}$ " determination (regression). The level significance of $r^{2}$ was assessed by the ANOVA test in Excel (Microsoft word, Version 2010). To determine the significant level of b value the student's t-test (ts) was used (i.e., $\mathrm{p}<0.05$ ).

\section{Result:}

A total 161 number of male and female species of Lepidocephalichthys guntea were taken up into account for the estimation of the length-weight relationship. Out of the collected species, three categories were made following male, female, and combination of male and female species for examination. Male species are distinguishable from the female through the observation of lamina circularis shaped by the fusion of the $7^{\text {th }}$ and $8^{\text {th }}$ pectoral rays (Present only in males)(Plate 1.c). Males are higher in numbers then the female among the collected species. The minimum and maximum values of length \& weight with standard deviations of them have been 
tabulated in Table 1. Female species have been recorded of highest length and male species of lowest length, in other hand female species were recorded with lowest $\&$ highest value of weight.

\section{Plate:}

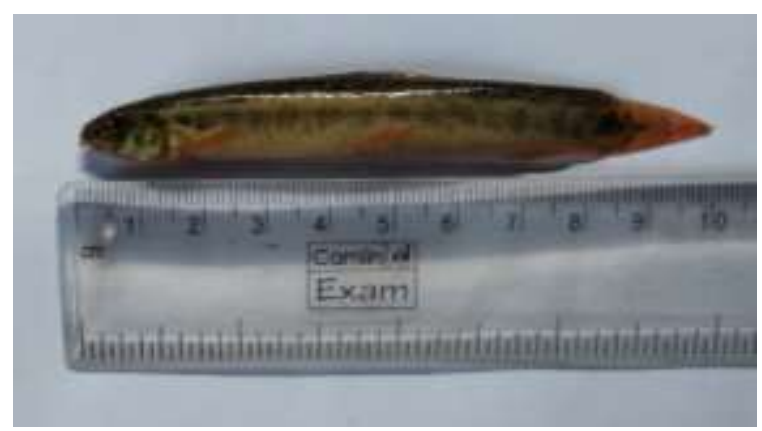

(1.a)

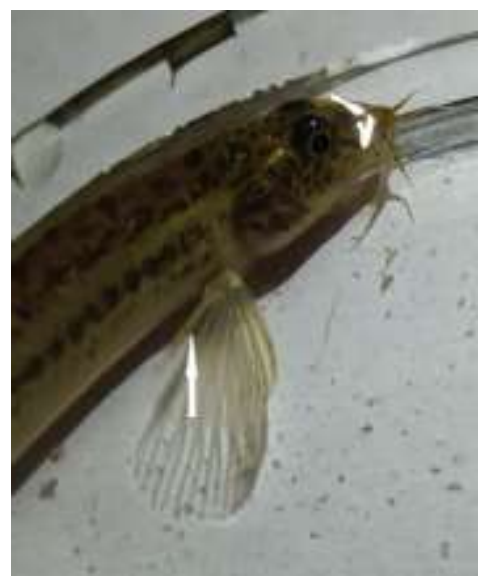

(1.c)

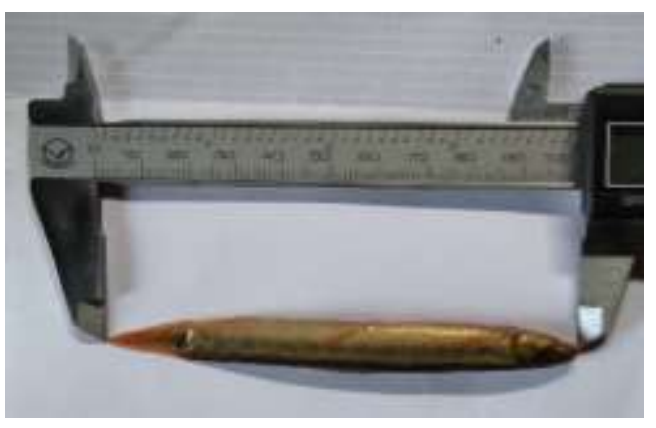

(1.b)

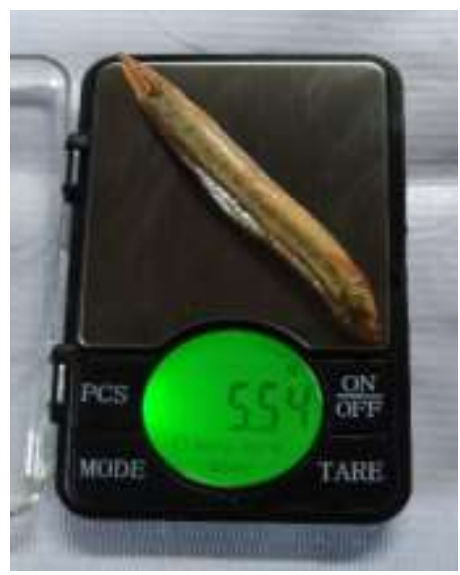

(1.d) 
Plate 1: (1.a) Species Lepidocephalichthys guntea, (1.b) Length measurement in digital vernier caliper, (1.c) Lamina circularis formed by the fusion of the $7^{\text {th }}$ and $8^{\text {th }}$ pectoral-fin rays, (1.d) Weight measurement of the species.

Table 1: The length and weight measurements of Lepidocephalichthys guntea.

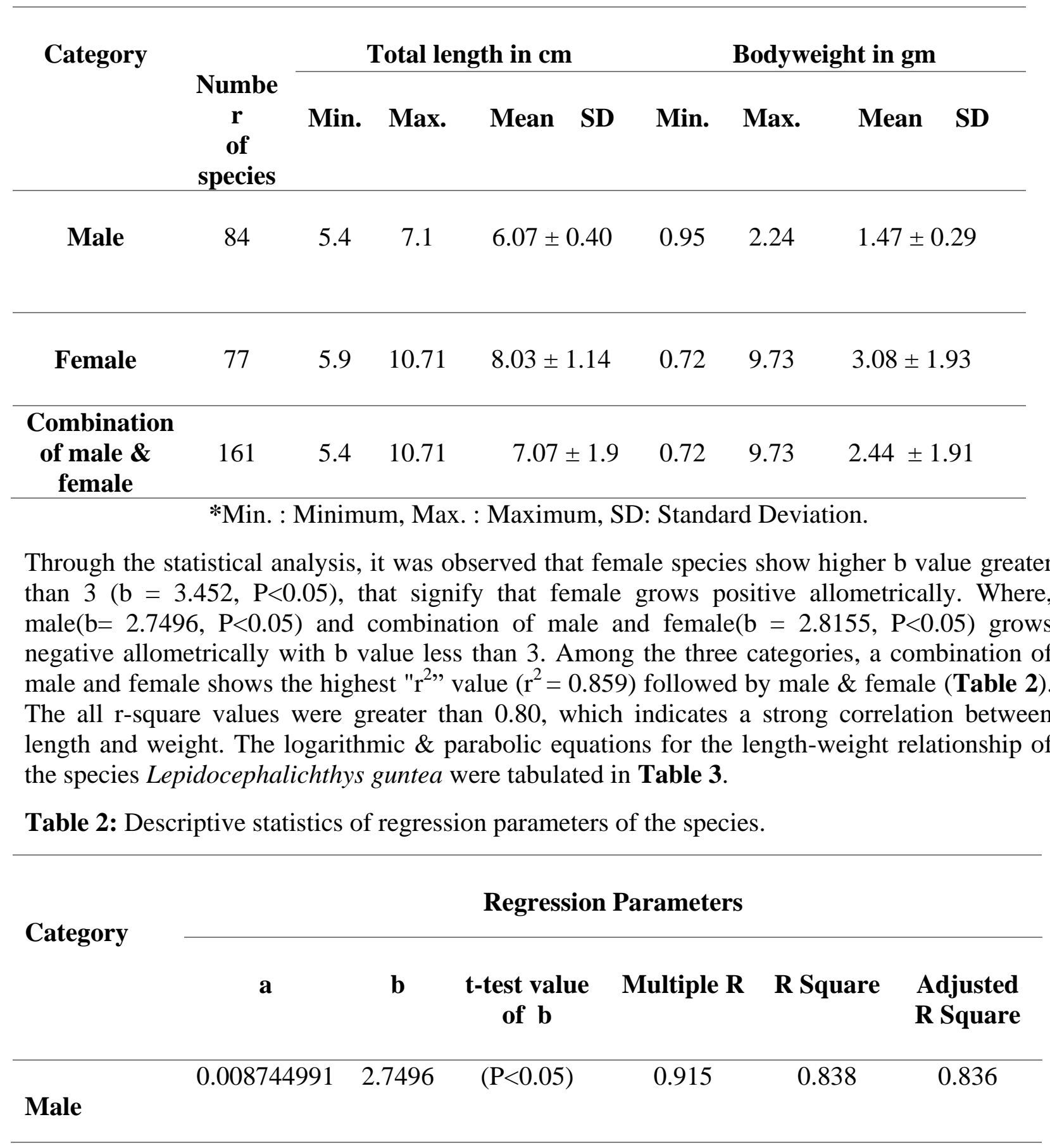


Female
0.002153098
3.452
$(\mathrm{P}<0.05)$
0.899
0.808
0.805

$\begin{array}{lllllll}\text { Combination } & 0.007575793 & 2.8155 & (\mathrm{P}<0.05) & 0.927 & 0.859 & 0.858\end{array}$

of male \&

female

$*_{\mathrm{a}}$ : intercept, b: slope, R: coefficient correlation.

Table 3: Descriptive logarithmic and parabolic equations of the species.

\begin{tabular}{lccc}
\hline Category & Logarithmic equations & $\begin{array}{c}\text { Correlation } \\
\text { coefficient }\end{array}$ & Parabolic equations \\
\hline Male & $\log \mathrm{W}=-2.05824+2.7496 \log \mathrm{TL}$ & 0.838 & $\mathrm{~W}=0.0087449991 \mathrm{~L}^{2.7496}$ \\
\hline & $\log \mathrm{W}=-2.66693+3.452 \log \mathrm{TL}$ & 0.808 & $\mathrm{~W}=0.002153098 \mathrm{~L}^{3.452}$ \\
\hline $\begin{array}{l}\text { Female } \\
\begin{array}{l}\text { Combination } \\
\text { of male \& } \\
\text { female }\end{array}\end{array}$ & $\log \mathrm{W}=-2.12057+2.8155 \log \mathrm{TL}$ & 0.859 & $\mathrm{~W}=0.007575793 \mathrm{~L}^{2.8155}$ \\
\hline
\end{tabular}

*TL: Total length, W: Weight, L: Length.

Table 4: Descriptive condition factor of the species.

\begin{tabular}{lcccccc}
\hline Category & \multicolumn{5}{c}{ Condition Factors (K) } \\
\cline { 2 - 7 } & \multicolumn{2}{c}{ Condition Factor (Fulton, 1904) } & \multicolumn{3}{c}{$\begin{array}{c}\text { Relative condition factor } \\
\text { (Le Cren, 1951) }\end{array}$} \\
\cline { 2 - 7 } & Min. & Max. & Mean SD & Min. & Max. & Mean SD \\
\hline Male & 0.544 & 0.757 & $0.654 \pm 0.05$ & 1.017 & 1.362 & $1.174 \pm 0.09$ \\
\hline Female & 0.336 & 0.957 & $0.539 \pm 0.14$ & 0.636 & 1.566 & $0.979 \pm 0.24$ \\
\hline $\begin{array}{l}\text { Combination } \\
\text { of male \& } \\
\text { female }\end{array}$ & 0.336 & 0.957 & $0.612 \pm 0.12$ & 0.641 & 1.934 & $1.155 \pm 0.23$ \\
\hline
\end{tabular}

*Min. : Minimum, Max. : Maximum, SD: Standard Deviation.

As, male species has logarithmic equation $\log \mathrm{W}=-2.05824+2.7496 \log \mathrm{TL}$ and parabolic equation $\mathrm{W}=0.008744991 \mathrm{~L}^{2.7496}$. The health conditions of a fish species could be estimated by observing the K-value, known as the condition factor. The average Fulton condition factor was found to be higher in the male category $(\mathrm{K}=0.654)$ and lower in the female category $(\mathrm{K}=$ 0.539). The average relative condition factor was higher in males (1.174) and lower in females 
(0.979). The Fulton and Relative condition factors were found to be varied maximum in female categories with SD values $0.14 \& 0.24$ respectively (Table 4). On intrigue the observed $\log$ weight of Lepidocephalichthys guntea contrary to the observed log length, a linear straight line was obtained which shows the strong relationship among length and weight with $r$ square range from 0.808 to 0.859 , a combination of male and female show the highest correlation $(0.859$, $\mathrm{P}<0.05)$ and female categories show the lowest correlation $(0.808, \mathrm{P}<0.05)($ Fig. 1, 2, and 3).

Fig 1: Length-weight relationship of male species (Log value).

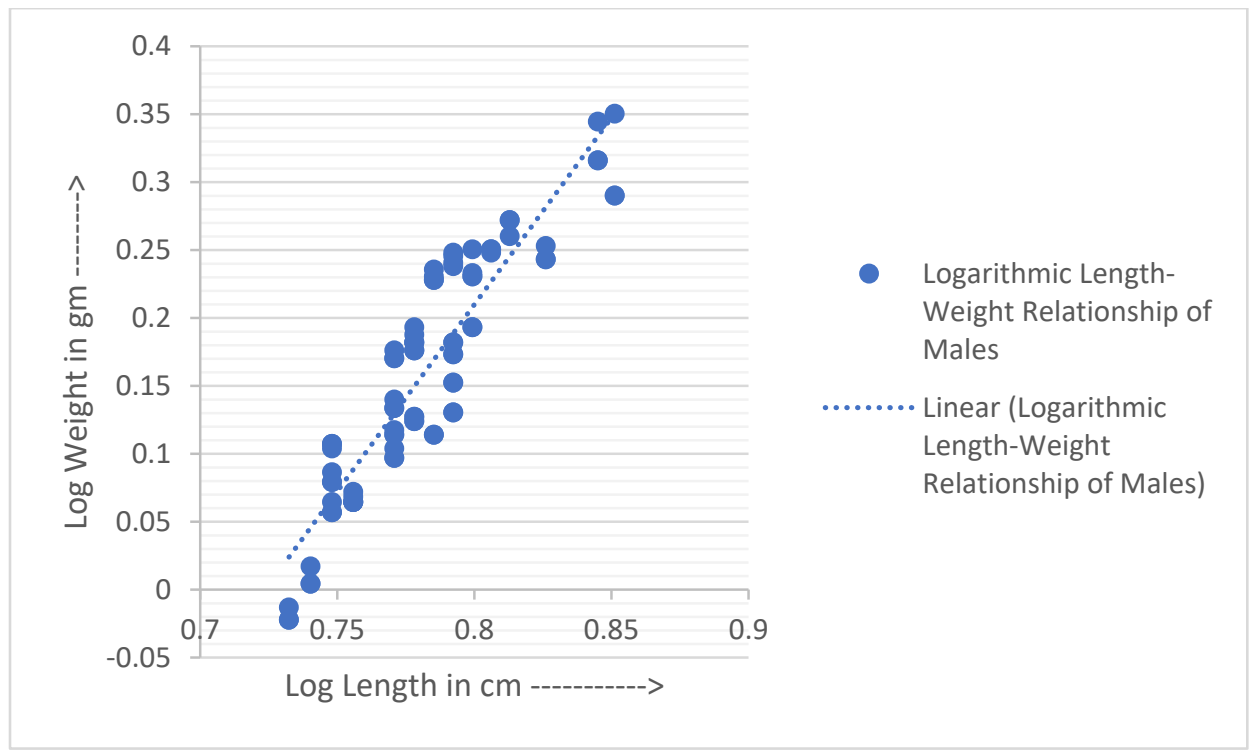

Fig 2: Length-weight relationship of female species (Log value). 


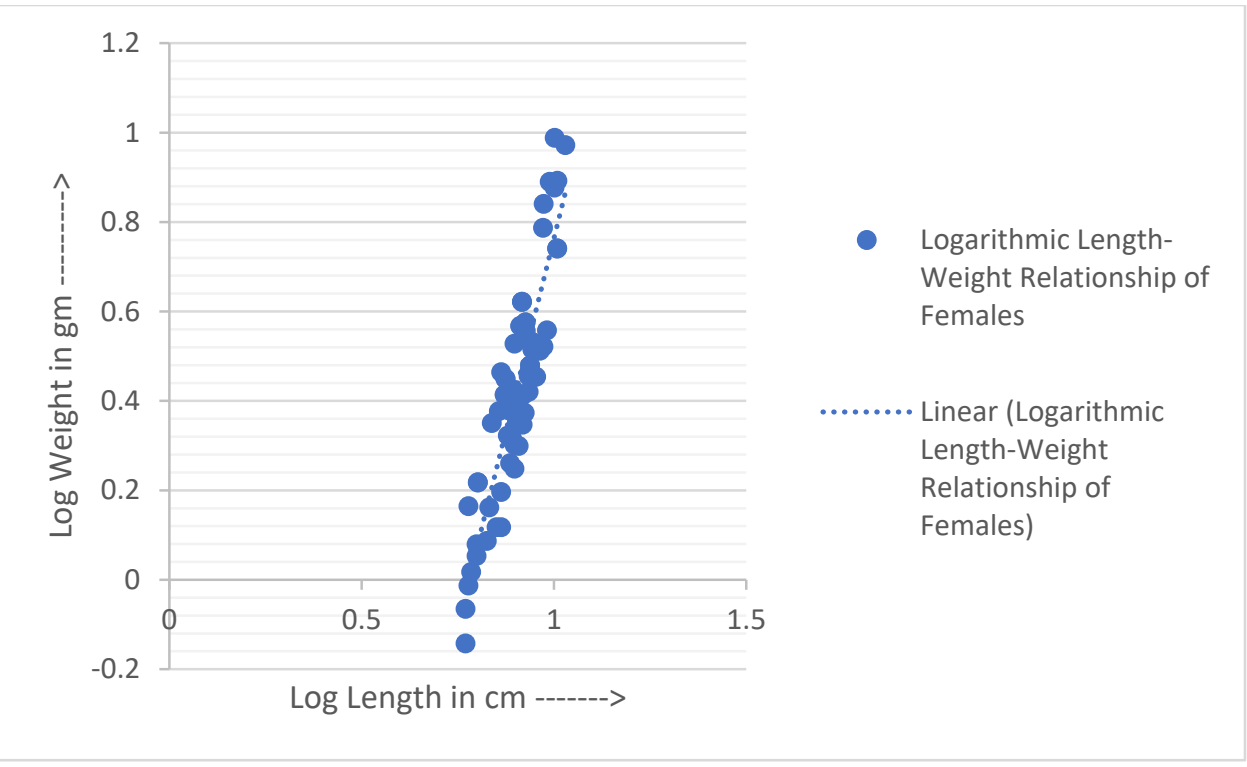

Fig 3: Length-weight relationship of combination of male \& female species (Log value).

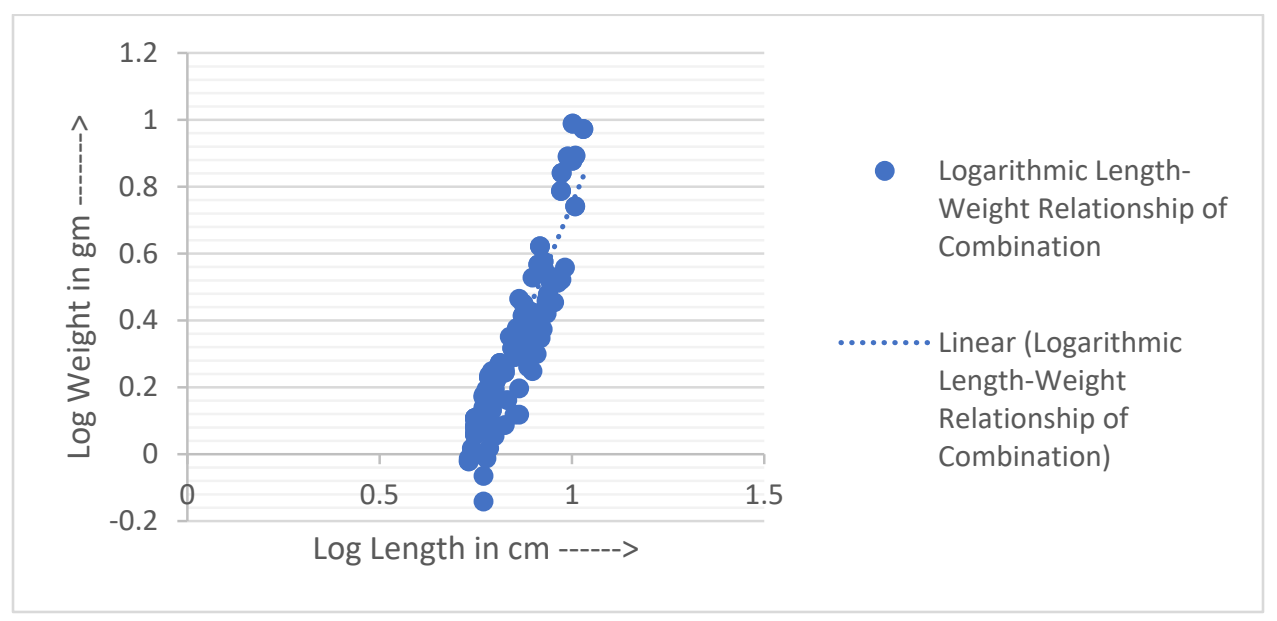

\section{Discussion:}

The relationship between length-weight is a very significant tool in the assessment of fisheries (Haimovidici and Velasco, 2000; Arslan et al., 2004) and also biomass of standing crop can be assessed grounded on length-weight value (Morey et al., 2003). The present study was carried out using a total 161 number of male and female species of Lepidocephalichthys guntea. As the population of this species decreasing day by day in their natural habitat, to know the growth pattern and health of this species, an examination has been done on the length-weight relationship from the Kangsabati river at West Midnapore district of West Bengal. From the study, it was observed that the numbers of male species were more than that of female species out of the collected species. The minimum size was observed in the male population and 
maximum size in the female population with varying weight, because at maturity within the same length group of males \& females, the female species show greater weight due to the development of ovary in the breeding season (Dhakal and Subba, 2003). Indeed the "b" value was found to be highest in the female category following combined categories and lower in the male categories. In the female, the " $b$ " value was greater than 3 which is $3.452(\mathrm{P}<0.05)$, which employs positive allometric growth with more increases in weight than the length. The grater " $b$ " value is due to an increase in the weight of females in contrast to the upsurge in length because massive growth of gonads in the breeding season which was also similar to the previous finding of Dhakal \& Subba (2003) ( $b=3.18)$. The gonadal developmental stages of female species, particularly the ovary which affect the weight (Weatherly, 1972 and Hile, 1936)of different species populations (Jhingran, 1968) and the state of maturity (Frost, 1945). In the male category, the " $b$ " value was found to be less than 3 , that is $2.7496(\mathrm{P}<0.05)$ which employs negative allometric growth. An alike pattern of negative allometric growth was reported in C. carpio from the amalgamated fish culture unit of Himachal Pradesh with the "b" values of 2.9002 (Jhingran,1952), open water system like from Gobindsagar with "b" value 2.42(Sharma,1986), Dal lake with "b" value 2.98 (Sunder,1984). By observing the "b" value of males it could be said that, increase in weight in males is not proportional to the rise in length of the body, the reason may be due to the energy losses for gonadal development rather than the somatic body development (Bura gohain and Goswami, 2013). In the case of the combination of male and female species the "b" value was found to be slightly greater than male and lesser than female, which is $2.8155(\mathrm{P}<0.05)$ \& shows negative allometric growth. Rahman et al., 1997 conveyed that, the "b" value of Lepidocephalichthys guntea for females (3.23), male (3.32), and combined (3.27) in Bangladesh. Some authors also itemized different " $b$ " values of this species, specifically Hossain, 2010 ( $b=3.64)$, Ferdaushy and Alam, 2015 ( $b=2.84)$, Hossain et al., 2009 $(b=3.25)$. The degree of alteration of " $b$ " value depends on the sex of the species (Hile and Jobes, 1940), feeding habit \& rates (Le Cren, 1951), gonadal developmental stages, specifically the ovary of female effect the weight of species (Weatherly, 1972 and Hile, 1936) diverse species population (Jhingran, 1968) and maturity state (Frost, 1945). The "a" \& "b" value differed among the same species reliant on the sex, maturity stages, and food habits (Qasim, 1973 and Bal \& Rao, 1984).

Among all the three categories the coefficient of correlation found to be higher in combination of male and female $\left(\mathrm{r}^{2}=0.859, \mathrm{P}<0.05\right)$, male $\left(\mathrm{r}^{2}=0.838, \mathrm{P}<0.05\right) \&$ female $\left(\mathrm{r}^{2}=0.808\right.$, $\mathrm{P}<0.05)$ category, showing a strong length-weight relationship , that are positively correlated \& vice versa(Fig. 1,2, \& 3) which are similar to the finding of Dhakal \& Subba (2003). In the natural habitat, the "K" (condition factor) or "Kn" (relative condition factor) value also governs the well-being of any fish species. According to Le Cren (1951), the "Kn" value greater than 1 specified the good condition of the fish species. The average relative condition factor of the male category was found to be greater than 1 and highest among the three categories, that is "Kn" value of 1.174 followed by combined male \& female category("Kn" value 1.155). The female category shows "Kn" value less than 1 but nearer to 1 , that is $0.979 \&$ this "Kn" is nearly similar to the finding of Gohain and Deka (2017), The lower 'Kn' values of females may be due to low gonadal maturity(Das et. al, 2019). The reflection is similar to the finding of DaCosta(2003) and proposed that a larger portion of the energy is owed for the growth and evacuation of ovaries leads to relatively lesser "Kn" values. So, the male category shows higher well-being condition among the three categories, which were taken into consideration for the examination of lengthweight relationship \& condition factor. 


\section{Conclusion:}

The current study it is revealed that the Lepidocephalichthys guntea from the river Kangsabati at West Bengal shows an allometric growth pattern with a "b" value not equal to 3 . So, it can be concluded that this species did not follow the proposed cube law strictly. This species shows a strong relationship among the length \& weight in this river system. The condition factor \& relative condition factor were found to be in a standard position to keep the well-being of the fish species in a healthy condition. This study has fulfilled the projected aim set for it, \& the presented data might create a valuable recommendation for founding forthcoming biometric studies for the fish collected over the Kangsabati River.

\section{Reference:}

Ali, A.N., Dahanukar, R., and Raghavan. (2013). Length-weight and length-length relationship of three species of snakehead fish, Channadiplo gramma, C. maruliusand C. striata from the riverine reaches of Lake Vembanad, Kerala, India. Journal of Threatened Taxa, 5(13), 4769-4773

Amponsah, S. K. K., Commey, N. A., Avornyo, S. Y., and Afranewaa, N. A. B.(2021). Length-weight relationships of six marine fish species from the coast of Ghana. J Appl Ichthyol. 2021;00:1-3. DOI: 10.1111/jai.14199

Araneda, M., Perez, P. E. and Gasca-Leyva, E.(2008). White shrimp Penaeus vannamei culture in freshwater at three densities: condition state based on length and weight. Aquaculture, 283: $13-18$.

Azadi, M. A., and Naser, A.(1996). Length-weight relationship and relative condition factor of carp, Labeo bata (Ham.) Kaptai reservoir, Bangladesh. Chittagong Univ. Stud. part II, 20 (2): $19-25$

Bal, D.V., Rao, K.V.(1984). Marine Fisheries. Tata McGraw- Hill publishing company, New Delhi.

Brody, S.(1945). Bioenergetics and growth. Reichhold Publishing Corporation, New York, 1023 pp.

Bura, G. A., Goswami, M.M.(2013). A study on Length-weight relationship and condition factor in the different age groups of Clarias magur (Hamilton, 1882) in Wetland aqua habitat of Assam, India. Aquacult; 14(1-2):65- 70.

DaCosta, M.R., Araujo, F.G.(2003). Length-weight relationship and condition factor of Microponias furniture (Desmarest) (Perciformes, Sciaenidae) in the Sepatiba Bay, Rio de Janeiro State, Brazil. Rev. Bras. Zool.; 20(4):685- 690.

Das, S.C.S., Joshi, K.D., Chakraborty, S.K., Panda, D., and Jaiswar, A.K.(2019). Length-weight relationship and condition factor of Cyprinus carpio Linnaeus, 1758 from the river Ganga, Allahabad, India. Journal of Entomology and Zoology Studies 2019; 7(3): 1420-1424

Dasgupta, M.(1988). Length-weight relationship and condition factor of the copper Maheer, Acrosscheilus hexagonolepis (McClelland). Matsya, 14: 79-91. 
Dhakal, A., Subba, B.R.(2003).Length-weight Relationship of Pathri Khola, Morang District. Our Nature.; 1:53- 57.

Dhasmana, N. N., and Lal, M. S.(1993). Length-weight relationship of a hill stream fish Garra gotyla (Gray). In: Singh, H. R. (Ed.),.Advances in limnology. Narendra Publishing House, Delhi, p. 291-298.

Eduardo, L.N., Frédou, T., Lira, A.S., Silva, L.V.S., Ferreira, B.P., Bertrand, A., Menard, F., Lucena-Fredou, F.(2019). Length-weight relationship of thirteen demersal fishes from the tropical Brazilian continental shelf. J Appl Ichthyol 35(2):590-59

Ferdaushy, M.H., Alam, M.M.(2015). Length-length and length-weight relationships and condition factor of nine freshwater fish species of Nageshwari, Bangladesh. Int. J. Aquat. Biol; 3(3):149-154.

Froese, R.(2006). Cube law, condition factor, and weight-length relationships: history, metaanalysis, and recommendations. Journal of Applied Ichthyology, 22(4), 241-253.

Frost, W.E.(1945). The age and growth of eels (Anguilla anguilla) from the Windermere catchment area. Part 2. J. Anim. Ecol.; 4:106-124.

Fulton, T. W.(1904). The rate of growth of fishes. 22nd Annual Report, Part III. Fisheries Board of Scotland, Edinburgh, pp. 141-241.

George, J. P., Sharma, A. K., Venketeshvaran, K., Sinha, P. S. R. K., Venugopal, G. and Biradhar, R. S. (1985). Length-weight relationship and relative condition factor in Cirrhina mrigala and Labeo rohita from sewage fed tank. Ann. Zool., Vol. XXIII, Pt. 2.

Gohain, A.B., and Deka, P.(2017). Length-weight relationship and relative condition factor of Lepidocephalichthys Guntea (Hamilton, 1822) of Ghati Beel of Dhemaji district of Assam, India. International Journal of Fisheries and Aquatic Studies 2017; 5(2): 514-517

Goncalves, J. M. S., Bentes, L., Lino, P. G., Ribeiro, J., Canario, A. V. M. and Erzinin, K.(1997). Weight-length relationships for selected fish species of small-scale demersal fisheries of the south and south-west coast of Portugal. Fish. Res., 30: 253- 256.

Gurkan, S., and Taskavak, E.(2007). Length-weight relationships for syngnathid fishes of the Aegean Sea, Turkey. Belgian Journal of Zoology, 137(2), 219.

Habib, A., Hanizar, M.I.A., Kamal, M.S., Azmi, M.A.S., and Seah, Y.G.(2021). Length-Weight Relationships of Four Demersal Fish Species from Chendering, Terengganu, Malaysia. Thalassas: An International Journal of Marine Sciences (2021) 37:205-207. https://doi.org/10.1007/s41208-021-00285-5

Haimovici, M., and Velasco, G.(2000). Length-weight relationship of marine fishes from southern Brazil. Naga, The ICLARM Quarterly, 23(1), 19-23.

Hamilton, E.(1822). An account of the fishes found in the River Ganges and its branches. Edinburgh: Archibald Constable and London: Hurst, Ribinson. 
Havird, C., and Page, L. M.(2010). A revision of Lepidocephalichthys (Teleostei: Cobitidae) with descriptions of two new species from Thailand, Laos, Vietnam, and Myanmar. Copeia, 1: 137-159.

Hile, R., Jobes, F.W.(1940). Age, growth, and production of the yellow perch Perca flavescens (Mitchill), of Saginaw Baya. Trans. Am. Fish Wash. 48:211-217.

Hile, R.(1936). Age and growth of Leucichthys artedi in the lakes of the northern Himalayan mahseer with reference to its fishery. Indian J Anim Sci. 55(1):65-67.

Hossain, M. Y., Ahmed, Z. F., Leunda, P. M., Jasmine, S., Oscoz, J., Miranda, R. and Ohtomi, J.(2006). Condition, length-weight, and length-length relationships of the Asian striped catfish Mystus vittatus (Bloch, 1794) (Siluriformes: Bagridae) in the Mathabhanga River, south-western Bangladesh. J. Appl. Ichthyol., 22: 304-307.

Hossain, M.Y.(2010).Morphometric Relationships of Length-weight and Length-length of Four cyprinid small Indigenous fish species from the Padma River (NW Bangladesh). Turk. J. Fish. Aquat. Sci. 10:131-134.

Hossain, M.Y., Jasmine, S., Ibrahim, H.M., Ahmed, Z.F., Rahman, M.M., Ohtomi, J., et al.(2009). Length-weight and length-length relationships of 10 small fish species from the Ganges, Bangladesh. J. Appl. Ichthyol. 25:117- 119.

Iqbal, T.H., Damora, A., Fikri, I.A., Tetelepta, J.M.S., Kembaren, D.D., Yusuf, M., and Habibi, A.(2018). Length-weight relationships of three reef fish species from Kei Islands, Southeast Maluku, Indonesia. IOP Conf. Series: Earth and Environmental Science 216 (2018) 012028. DOI:10.1088/1755-1315/216/1/012028

Jhingran, V.G.(1952). General length-weight relationship of three major carps in India, Proc. Nat. Inst. Sci. India. 17:559-560.

King, M.(2007). Fisheries biology, assessment, and management. Wiley Blackwell, 400P.

Kolher, N., Casey, J. and Turner, P.(1995). Length-weight relationships for 13 species of sharks from the Western North Atlantic. Fish. Bull. NOAA, 93: 412-418.

Kumar, R., Abujam, s., Darshan, A., Kumari, a., Das, D. N.(2017). Length-Weight Relationship of Lepidocephalichthys guntea (Hamilton, 1822) From Dikrong River, Arunachal Pradesh. WWJMRD 2017;4(2): 197-200

Lagler, K. F.(1952). Freshwater fishery biology. Wim C Brown Co., Dubugue, Iowa, 360 pp

Lal, M. S., and Dwivedi, A. S.(1965). Studies on the biology and fishery of some freshwater fishes of U. P - Length-weight relationship of Rita rita. Ichthyol., 4: 21-26

Le Cren, E. D.(1951).The length-weight relationships and seasonal cycle in gonad weight and condition in the perch (Perca fluviatilis). J. Anim. Ecol. 20, 201-219.

Lopez, M.E., Ruiz, N.S., Alejandra, M.(2020). Length-weight relationship of four demersal species from the san Matías Gulf, Patagonia, Argentina. Pan-Am J Aquat Sci 15(1):2832 
Martin-Smith, K.M.(1996). Length/weight relationships of fishes in a diverse tropical freshwater community, Sabah, Malaysia. Journal of Fish Biology, 49(4), 731- 734.

Morato, T. P., Afonso, P., Lourinho, P., Barreiros, J. P., Santos, R. S. and Nash, R. D. M.(2001). Length-weight relationships for 21 coastal fish species of the Azores, North-Eastern Atlantic. Fish. Res., 50: 297-302.

Narasimham, K. A.(1970). On the length-weight relationship and relative condition in Trichiurus lepturus (Linnaeus). Indian J. Fish., 17 (1-2): 90-96.

Narejo, N. T., Rahmatullah, S. M. and Mamnur Rashid, M.(2002). Length-weight relationship and relative condition factor (Kn) of Monopterus cuchia (Hamilton). Indian J. Fish., 49 (3): 329-333.

Ortega-Garcia, S., Sepulveda, C., Aalbers, S., Jakes-Cota, U., RodriguezSanchez, R.(2017). Age, growth, and length-weight relationship of roosterfish (Nematistius pectoralis) in the eastern Pacific Ocean. Fish Bull 115:117-124

Ozaydin, O., Uckun, D., Akalin, S., Leblebici, S. and Tosunoglu, Z.(2007). Length-weight relationships of fishes captured from Izmir Bay, Central Aegean Sea.J. Appl. Ichthyol.23,695-696

Pal, M., Mahapatra, B.K., Mondal, B.(2013). Length-Weight Relationship and Condition Factor of Puntius sophomore (Hamilton, 1822) Collected from Kolkata and Sub Urban Fish Markets. Environment \& Ecology 31 (3) : 1255-1259

Pal, M., Mahapatra, B.K., Mondal, B., Roy, A. K.(2014). Length-Weight Relationship and Condition Factor of Amblypharyngodon mola (Hamilton-Buchanan, 1822). J. Indian Soc. Costal agric. Res. 32(1): 54-58

Panicker, B.A., and Katchi, VI.(2021). Length-weight relationship and relative condition factor of goby fish, Paracheaturichthys ocellatus (Day 1873) from the creeks of Mumbai. International Journal of Fisheries and Aquatic Studies 2021; 9(2): 151-157. DOI: https://doi.org/10.22271/fish.2021.v9.i2c.2432

Pathak, S. C.(1975). Length-weight relationship, condition factor, and food study of Labeo calbasu (Hamilton) from Loni reservoir (MP). J. Inland Fish. Soc. India, VII: 58-64

Pauly, D.(1993). Fishbyte. Section editorial. Naga, The ICLARM Quarterly, 16(2-3), 26-27.

Petrakis, G., and Stergiou, K.I.(1995). Weight-length relationships for 33 fish species in Greek waters. Fisheries Research, 21(3-4), 465- 469.

Qasim, S.Z.(1972).an appraisal of the studies on maturation and spawning in marine teleosts from the Indian waters. Indian. J. Fish.2:166-181.

Sharma, V.K.(1986). The biology and fishery of Cyprinus carpio Linn, from the Gobindsagar Reservoir, Himachal Pradesh, India. Thesis Abst. Matsya.12- 13:231. 
Shrivastava, S., and Pandey, A. K.(1981). Length-weight relationship and condition factor of three Indian major carps in composite fish farming. Matsya, 7: 70-74.

Siddique, M.A.M., Khan, M.S.K., Habib, A., Bhuiyan, M.K.A., Aftabuddin, S.(2016). Size frequency and length-weight relationships of three semi-tropical cephalopods, Indian squid Photololigo duvaucelii, needle cuttlefish Sepia aculeata, and spineless cuttlefish Sepiella inermis from the coastal waters of Bangladesh, bay of Bengal. Zool Ecol 26(3):176-180

Soni, D. D., and Kathal, K. M.(1979). Length-weight relationship in Cirrhinus mrigala (Val.) and Cyprinus carpio (Hamilton). Matsya, 5: 69-72.

Stergiou, K. I., and Moutopoulos, D. K.(2001). A review of length-weight relationships of fishes from Greek marine waters. NAGA, ICLARM Quart., 24(1-2): 23-39.

Sunder, S., Kumar, K., Raina, H.S.(1984). Food and feeding habits and length-weight relationship of Cyprinus carpio var. specularis of Dal Lake, Kashmir. Indian. J Fish. 31(1):90-99.

Talwar, P. K., Jhingran, A. G.(1991) Inland fishes of India and adjacent countries (Vols. 1\&2). Oxford and IBH Publishing Co. Pvt. Ltd., New Delhi, pp. 1158.

Ujjania, N.C., Kohli, M.P.S. and Sharma, L.L.(2012). Length-weight relationship and condition factors of Indian major carps (Catla catla, Labeo rohita, and Cirrhinus mrigala) in Mahi Bajaj Sagar, India. Research Journal of Biology, 2(1), 30-36.

Weatherly, A.H.(1972). Growth and ecology of the fish population. Academic Press, London.

www.iucnred.list.( 2017) 04 February.

Zaydın, O. O., Uckun, D., Akalın, S., Leblebici, S., and Tosunog`lu, Z.(2007).Length-weight relationships of fishes captured from Izmir Bay, Central Aegean Sea. J. Appl. Ichthyol. 23 (2007), 695-696. DOI: 10.1111/j.1439-0426.2007.00853. 